\title{
Kemampuan Membaca Pemahaman Mahasiswa di Lamongan
}

\author{
Abdul Kholiq \\ Universitas Islam Lamongan \\ abdulkholiq@unisla.ac.id
}

DOI: http://dx.doi.org/10.32528/bb.v5i2.3216

First received: 05-05-2020

Final proof received: 22-09-2020

\begin{abstract}
ABSTRAK
Penelitian ini bertujuan untuk menganalisis tingkat membaca pemahaman mahasiswa di Kabupaten Lamongan. Fokus penelitian ini adalah tingkat pemahaman literal, inferensial, kritis, dan kreatif mahasiswa di Kabupaten Lamongan. Penelitian ini menggunakan pendekatan kuantitatif deskriptif. Sampel penelitian ini adalah 373 mahasiswa Islam Lamongan; 353 mahasiswa Islam Darul 'Ulum Lamongan; 222 Universitas Billfath Lamongan. Pengumpulan data dalam penelitian ini menggunakan tes. Tes berisikan empat puluh pertanyaan dengan masingmasing sepuluh pertanyaan untuk mengukur tingkat pemahaman literal, inferensial, kritis, dan kreatif. Penganalisisan data penelitian ini adalah dengan mencari nilai rata-rata perolehan pemahaman. Penentuan kategori tingkat pemahaman menggunakan menggunakan lima kategori dengan skala $0-100$, yaitu sangat rendah $(0-20)$, rendah $(20-40)$, sedang (40 - 60), tinggi $(60-80)$, dan sangat tinggi (80-100). Hasil dari penelitian menunjukkan bahwa Tingkat pemahaman literal mahasiswa di Kabupaten Lamongan sebesar 64,12 dengan kategori tinggi. Tingkat pemahaman inferensial mahasiswa di Kabupaten Lamongan sebesar 57,95 dengan kategori sedang. Tingkat pemahaman ktitis mahasiswa di Kabupaten Lamongan sebesar 61,49 dengan kategori tinggi. Tingkat pemahaman kreatif mahasiswa di Kabupaten Lamongan sebesar 44,25 dengan kategori sedang. Dari keempat hasil di atas, dapat disimpulkan bahwa tingkat membaca pemahaman mahasiswa di Kabupaten Lamongan berada pada tingkat sedang dengan rata-rata nilai pemahaman sebesar 56,95. Perolehan tersebut di atas rata-rata angka literasi nasional sebesar 37,32.

Keywords: Membaca Pemahaman; Pemahaman Literal; Pemahaman Inferensial; Pemahaman Kritis; Pemahaman kreatif
\end{abstract}

\begin{abstract}
This study aims to analyze the reading comprehension ability of college students in the Lamongan Regency. The focus research is the level of literal, inferential, critical, and creative comprehension of college students in the Lamongan Regency. This research uses descriptive quantitative. The sample of this study was 373 Universitas Islam Lamongan students; 353 students of Universitas Islam Darul 'Ulum
\end{abstract}


Lamongan; 222 Universitas Billfath Lamongan. Data collection used a test. The test contains forty questions with ten questions each to measure the level of literal, inferential, critical, and creative understanding. The data analysis of this research is to find the average value of the acquisition of understanding. Determination of the level of understanding categories using five categories with a scale of $0-100$, namely very low (0-20), low (20-40), medium (40-60), high (60-80), and very high (80100). The results of the study showed that the level of literal comprehension was 64.12 with a high category. The level of inferential comprehension was 57.95 in the medium category. The level of critical comprehension was 61.49 with a high category. The level of creative comprehension was 44.25 with a medium category. From the four results above, it can be concluded that the reading comprehension level of students in Lamongan Regency is at a moderate level with an average comprehension score of 56.95. The results are above the average national literacy rate of 37.32 .

\section{Keywords: Reading Comprehension; Literal Comprehension; Inferential Comprehension; Critical Comprehension; Creative Comprehension}

\section{INTRODUCTION}

In language learning, language skills are an important focus in developing students' language competencies. Language skills are defined as a person's ability to use their language competencies. This language skill consists of four types, namely listening, speaking, reading, and writing skills (Mulyati \& Isah, 2016; Pebriani, 2018). These four skills have their fields or aspects. Listening and reading skills are included in the skill type on the receptive sphere while speaking and writing skills are included in the productive aspect.

If linked to a degree of literacy, reading and writing skills have a role to determine the low level of a person's linguistic literacy. Furthermore, reading skills become a person to be able to improve their writing skills. Reading has a very important role in determining a person's cognitive level. The more reading, the more knowledge, and information gained (Fitri, 2015).

Reading is an interactive activity in exploring the meaning or meaning of a written language (Somadayo, 2011; Fitri, 2015). On the other hand, Sartika (2017) states that reading is a skill that is possessed by a person in obtaining the information directly from the author through the media of words or writings. In the process of reading internal and external skills involved. The internal factors in question concern intelligence, interests, talents, and others that concern within the reader. External factors involved in reading concerning the means of reading, the environment where reading, social-economic background, and reading habits (Irfadila, 2015). In some of the reading definition, it can mean that reading skills are skills that one has in understanding the information contained in the reading. Such information may be expressed and implied.

Reading has two types, namely extensive reading and intensive reading (Patiung, 2016). Extensive reading is interpreted as a cursory reading aimed at finding 
important information in the reading. Intensive reading is interpreted as an earnest reading. That is, intensive reading is a type of reading activity aimed at understanding the entire content in reading. Intensive reading consists of meticulous reading, reading comprehension, critical reading, reading ideas, and creative reading (Patiung, 2016). From this type of intensive reading, reading comprehension becomes a kind of reading that is widely used as a topic of learning in the classroom, both in the level of secondary education and higher levels of education.

Reading comprehension is interpreted as reading to gain a deep understanding of the text (Sartika, 2017). According to Laily (2014), reading comprehension is to read by understanding the contents of the reading by some question words, for example, what, how, why, where, and conclusions based on the problem of the content of the text. Meanwhile, Marhiyanto (2007) stated that reading comprehension skills require that one be able to capture sharper points of mind so that after completion of reading, he understands the meaning and purpose of the text. From some of these explanations, reading comprehension is a type of reading that aims to understand all the information on the readings, either expressed or implied. Furthermore, reading comprehension also aims to give a review of some of the statements in reading.

There are four levels of reading comprehension, namely literal comprehension, inferential comprehension, critical comprehension, and creative comprehension (Kholiq \& Luthfiyati, 2018). Literal comprehension is understanding at the lowest level. This comprehension relates to the mastery of the information that has been written in the reading. Inferential comprehension is a level of understanding of its literal comprehension. Inferential comprehension relates to the ability to understand information that is not written in reading or implied (Kholiq \& Luthfiyati, 2018). The two comprehensions are included in the lower order thinking skills (LOTS) (Kholiq \& Faridah, 2019).

Critical comprehension and creative comprehension are included in the higher order of Thinking Skills (HOTS) (Kholiq \& Faridah, 2019). Critical comprehension relates to the ability to assess the correct and incorrect statements of information in the text. Creative comprehension is the ability to create new ideas that are relevant to the text. This comprehension is the highest understanding of the level of reading comprehension. The creative understanding is equivalent to the cognitive ability in the revised Bloom taxonomy, namely in C6 (creating) (Gunawan \& Palupi, 2016).

According to Somadayo (2011), there are several factors the reading comprehension of students, among them, 1) Student Intelligence (intellectual) level; 2) linguistic ability (deprecation of language); 3) Psychological conditions (interests and emotions). The ability of a student will also be seen in the ability to read his understanding of reading. High low reading ability will be seen at the high and low ability to read understanding of the reading text (Pebriani, 2018). If a student is able to master reading comprehension well, the ability of the information literacy is good. Yulianto, Sodiq, \& Asteria, (2020) stated that reading comprehension is one of the main capabilities that play an important role in achieving information literacy competence. From that, student literacy will be high if the ability to read the understanding is high. 
Based on data from the OECD (2019), from the results of the Program for International Student Assessment (PISA), Indonesia occupied the country with a final order in the field of reading performance in 2018 with an average of 371 . The Reading performance referred to in PISA is measuring capacity in understanding, using, and reflecting written text to develop the knowledge and potential of students. The achievement, indicating that the Indonesian students reading of Indonesia is very low. That is, the ability to read understanding is also very low.

On the other hand, Solihin, Utama, Pratiwi, \& Novirina (2019) eported the index of literacy activities in 34 provinces in Indonesia with the index results of a low national literacy activity with an average number of 37.32. The average figure is derived from several dimensions of assessment, i.e. the proficiency dimension of 75.92; Access dimension of 23.09; An alternate dimension of 40.49; and cultural dimension of 28.50. The acquisition is in line with the OECD (2020) released data that states the reading of Indonesian students in the lower category.

Further, data on college student literacy also show the same results. Kholiq \& Faridah (2019) stated that the reading comprehension ability at the higher-order thinking skills (HOTS) was included in the low category with an average achievement of 50.13. The achievement supports previous data that not only the students in primary and secondary education are low reading literacy, but also in the students also show the same results.

From that data, indirectly the parties relating to education and human resources improvement have a heavy-duty to improve the reading ability of Indonesian students. One of them is to instill the importance of reading and increasing interest in Indonesian college students. The main purpose of the way is to improve the reading comprehension ability of college students.

In addition, research in the area of reading literacy level analysis must also be improved to find solutions to improve reading literacy of Indonesian students, both students at the elementary and secondary levels as well as at the higher education level. In recent decades, research that analyzed the level of reading comprehension of students began a lot. However, research that analyzes the level of reading comprehension of students is still not much done. Therefore, research on the level of reading comprehension in students is carried out with the aim of providing more data as a supporter of government policy.

Research on the level of reading comprehension in students can be carried out in areas where the results can be integrated. One area that already has a human development index in East Java is Lamongan Regency. by analyzing the level of reading comprehension of students in the Lamongan Regency is expected to provide data about the level of reading comprehension of students in the area.

This study aims to analyze the level of reading comprehension of college students in the Lamongan Regency. The focus of research is 1) the level of literal comprehension; 2) level of inferential comprehension; 3) the level of critical comprehension; and 4) the level of creative comprehension of college students in the Lamongan Regency. 


\section{METHOD OF RESEARCH}

This research uses a descriptive quantitative approach. The descriptive quantitative research is in line with the A Factor Study of the Literal Reading Comprehension Test and The Inferential Reading Comprehension Test (Pettit \& Cockriel, 1974). This research was conducted by giving a reading comprehension test to students about literal comprehension, inferential comprehension, critical comprehension, and creative comprehension of university students in the Lamongan Regency. The test that asks about literal and inferential understanding is adapted from the Inferential Reading Comprehension Test (IRC) and the Literal Reading Comprehension Test (LRC) (Pettit \& Cockriel, 1974).

The population of the study was all students at universities in Lamongan Regency consisting of 1) Universitas Islam Lamongan (Unisla) with a total of 5,509 students; 2) Universitas Islam Darul 'Ulum Lamongan (Unisda) with 2926 students; and 3) Universitas Billfath Lamongan (Billfath) with 498 students. The determination of the sample of respondents was carried out using the Slovin calculation formula (Hidayat, 2017). The sample of respondents with an error margin of 0.05 in this study was 1) 373 students of Universitas Islam Lamongan; 2) 353 students of Universitas Islam Darul 'Ulum Lamongan; 3) 222 students of Universitas Billfath Lamongan.

Data collection in this study used a test technique. The test consists of four readings, each reading consists of ten questions. The ten questions are related to questions related to the measurement of literal, inferential, critical, and creative comprehension. Of the forty questions in the text, each level of understanding is asked ten questions each.

Analyzing the data is done by finding the average value of understanding at each level. The average is adjusted by determining the category of reading comprehension level. Determination of the reading comprehension level category on a scale of 0-100 is grouped into 5 categories which are seen in the following table.

Table 1. Category of reading comprehension ability
\begin{tabular}{cc}
\hline Value & Category \\
\hline $0-20,00$ & Very low \\
\hline $20,01-40,00$ & Low \\
\hline $40,00-60,00$ & Medium \\
\hline $60,01-80,00$ & High \\
\hline $80,01-100$ & Very hig \\
\hline & Adapted from Solihin, Utama, Pratiwi, \& Novirina (2019)
\end{tabular}

\section{DISCUSSION}

\section{a. Literal Comprehension Ability of College Students in Lamongan Regency}

The topic of the question that was tested on the literal comprehension aspects of college students in the Lamongan Regency in each reading was to ask 1) the identity of the characters in the reading; 2) short form in reading; 3 ) the cause of the disaster in reading; 4) disaster management from reading; 5) the number of objects in the reading; 6) time of application of a policy; and 7) time for implementing the activity. From the 
seven topic questions, it was revealed to be ten literal comprehension questions spread on each given reading. Obtaining a literal comprehension of college students in the Lamongan Regency by statistical calculation is described in the following table.

Table 2 Literal Comprehension Ability of College Students in Lamongan Regency

\begin{tabular}{lcccc}
\hline & N & Min & Max & Mean \\
\hline unisla & 373 & 20 & 90 & 62.44 \\
\hline unisda & 353 & 20 & 80 & 58.44 \\
\hline billfath & 222 & 50 & 90 & 71.49 \\
\hline Mean & & & & $\mathbf{6 4 . 1 2}$
\end{tabular}

From Table 2, obtaining the maximum value of the literal comprehension of 90 students on the student Unisla and Billfath. If categorized in the level of reading, the value is included in the very high category. However, the acquisition of a minimum literal understanding value obtained was 20 for Unisla and Unisda students. The acquisition can be rated very low. With the results of the maximum and minimum values it can be said that the literal comprehension of students in Lamongan Regency has a high ability gap.

The average acquisition of a literal comprehension of college students in the Lamongan Regency was 64.12. This acquisition can be categorized as high. This student understanding ability is said to be reasonable because the level of student thinking has also increased compared to students at primary and secondary levels.

With the acquisition of an average literal comprehension of college students in Lamongan Regency of 64.12, it can be a comparison of values that are contradictory to the literacy activity index stated by Solihin, Utama, Pratiwi, \& Novirina (2019) that the Indonesian literacy rate is at an average rate 37.32. These results can be said to be normal because literal understanding is an understanding at the lowest level.

\section{b. Inferential Comprehension Ability of College Students in Lamongan Regency}

The topic of the question that was tested on the aspect of inferential comprehension of college students in the Lamongan Regency in each reading was to ask 1) the questions whose answers are implicit in the reading; 2) the meaning of certain words in the reading; 3) the historical order of the discovery of an instrument; 4) determination of the main ideas from the reading; 5) determining the meaning of words from reading; 6) main ideas of certain paragraphs in reading; 7) the problems raised in the reading; 8) the conclusion of a reading. From the eight topic questions, it is revealed to be ten questions of inferential comprehension that are spread on each given reading. Obtaining an inferential comprehension of college students in the Lamongan Regency by statistical calculation is described in the following table.

Table 3 Inferential Comprehension Ability of College Students in Lamongan Regency

\begin{tabular}{lcccc}
\hline & N & Min & Max & Mean \\
\hline Unisla & 373 & 20 & 80 & 52.92 \\
\hline Unisda & 353 & 30 & 90 & 59.49 \\
\hline Billfath & 221 & 20 & 90 & 61.45 \\
\hline Mean & & & & $\mathbf{5 7 . 9 5}$
\end{tabular}


From table 3, the maximum value of students' inferential comprehension is 90 for Unisda and Billfath students. If categorized in the level of reading, the value is included in the very high category. However, the acquisition of a minimum score of inferential comprehension was 20 for Unisla and Billfath students. The acquisition can be rated very low. These results indicate that college students in Lamongan regency have an inferential understanding that is at the same level as literal understanding

The average acquisition of an inferential comprehension of college students in the Lamongan Regency was 57.95. The acquisition can be categorized as medium. From these data, the literal and inferential comprehension abilities of college students in the Lamongan Regency are in the high categories. This shows that the level of reading comprehension of LOTS of students stated by Kholiq \& Faridah (2019) is in high category. This achievement positioned the understanding of student LOTS above the average Indonesian literacy index.

\section{c. Critical Comprehension Ability of College Students in Lamongan Regency}

The topic of the question that was tested on the aspect of critical comprehension of college students in the Lamongan Regency in each reading was to ask 1) the difference of the two statements in the reading; 2) determination of the correct statement of reading; 3) assessment of the objectives to be conveyed by the writer from the reading; 4) assessment of the use of the wrong word in paragraphs; 5) evaluation of incorrect statements from the reading; 6) the difference between the two objects in the reading; 7) statement of the attitude of one of the parties from the reading. The seven topic questions, down to ten critical comprehension questions spread over each given reading. The critical comprehension of college students in the Lamongan Regency by statistical calculation is described in the following table.

Table 4 Critical Comprehension Ability of College Students in Lamongan Regency

\begin{tabular}{lcccc}
\hline & N & Min & Max & Mean \\
\hline unisla & 373 & 20 & 100 & 60.03 \\
\hline unisda & 353 & 40 & 90 & 73.23 \\
\hline billfath & 222 & 10 & 90 & 51.22 \\
\hline Mean & & & & $\mathbf{6 1 . 4 9}$ \\
\hline
\end{tabular}

From table 4, the maximum value of the critical comprehension of students is 100 for Unisla students. If categorized in the level of reading, the value is included in the very high category. However, the acquisition of the minimum critical comprehension value obtained was 10 for Billfath students. The acquisition can be rated very low. Supposedly, the acquisition of critical comprehension results is lower than literal and inferential comprehension. The critical comprehension conveyed by Kholiq \& Luthfiyati (2018) is interpreted as a higher understanding than literal and inferential. However, the acquisition of the maximum value of critical comprehension of college students in the Lamongan Regency is higher than that of literal and inferential comprehension. This shows that there are some students who have a high critical ability. 
Meanwhile, the average critical comprehension of college students in the Lamongan Regency was 61.49. This acquisition can be categorized as high. The acquisition supports the discussion of the maximum and minimum critical data scores of college students in the Lamongan Regency. The difference in value is also in conflict with the Indonesian literacy index (Solihin, Utama, Pratiwi, \& Novirina, 2019).

\section{d. Creative Comprehension Ability of College Students in Lamongan Regency}

The topic of the questions that were tested on the aspects of creative comprehension of college students in the Lamongan Regency in each reading was 1) Completing words that were missing in sentences; 2) Completing sentence that overlaps in paragraphs; 3) Determine the right topic to continue reading. These three question topics were revealed as ten questions of creative understanding spread over each given reading. The acquisition of a creative comprehension of college students in the Lamongan Regency by statistical calculation is described in the following table.

Table 5 Creative Comprehension Ability of College Students in Lamongan Regency

\begin{tabular}{lcccc}
\hline & $\mathbf{N}$ & Min & Max & Mean \\
\hline Unisla & 373 & 10 & 80 & 41.47 \\
\hline Unisda & 353 & 30 & 90 & 50.82 \\
\hline Billfath & 222 & 10 & 70 & 40.45 \\
\hline Mean & & & & $\mathbf{4 4 . 2 5}$ \\
\hline
\end{tabular}

From table 5, the acquisition of a maximum value of 90 students' creative comprehension at Unisda students. If categorized in the level of reading in table 1, the value is included in the very high category. However, the acquisition of the minimum creative comprehension value obtained was 10 for Unisla and Billfath students. The acquisition can be rated very low. With this acquisition, there are several conditions that are in harmony with the concept of creative comprehension. Supposedly, the acquisition of creative comprehension results is lower than other comprehension level. Creative comprehension that has been conveyed by Kholiq \& Luthfiyati (2018) is interpreted as the highest comprehension than other levels. That it is possible the value obtained in creative comprehension will be the lowest value.

Meanwhile, the creative comprehension of college students in the Lamongan Regency was 44.25. The acquisition can be categorized as moderate. The acquisition contradicts data from Solihin, Utama, Pratiwi, \& Novirina (2019) which states that Indonesia's literacy rate is at an average of 37.32. From this, it can be said that college students in Lamongan Regency have a higher creative comprehension than the average Indonesian literacy index.

\section{e. Reading Comprehension Ability of College Students in Lamongan Regency}

From the acquisition of the average value of literal, inferential, critical, and creative comprehension, the level of reading comprehension of college students in the Lamongan Regency can be observed in the following chart. 


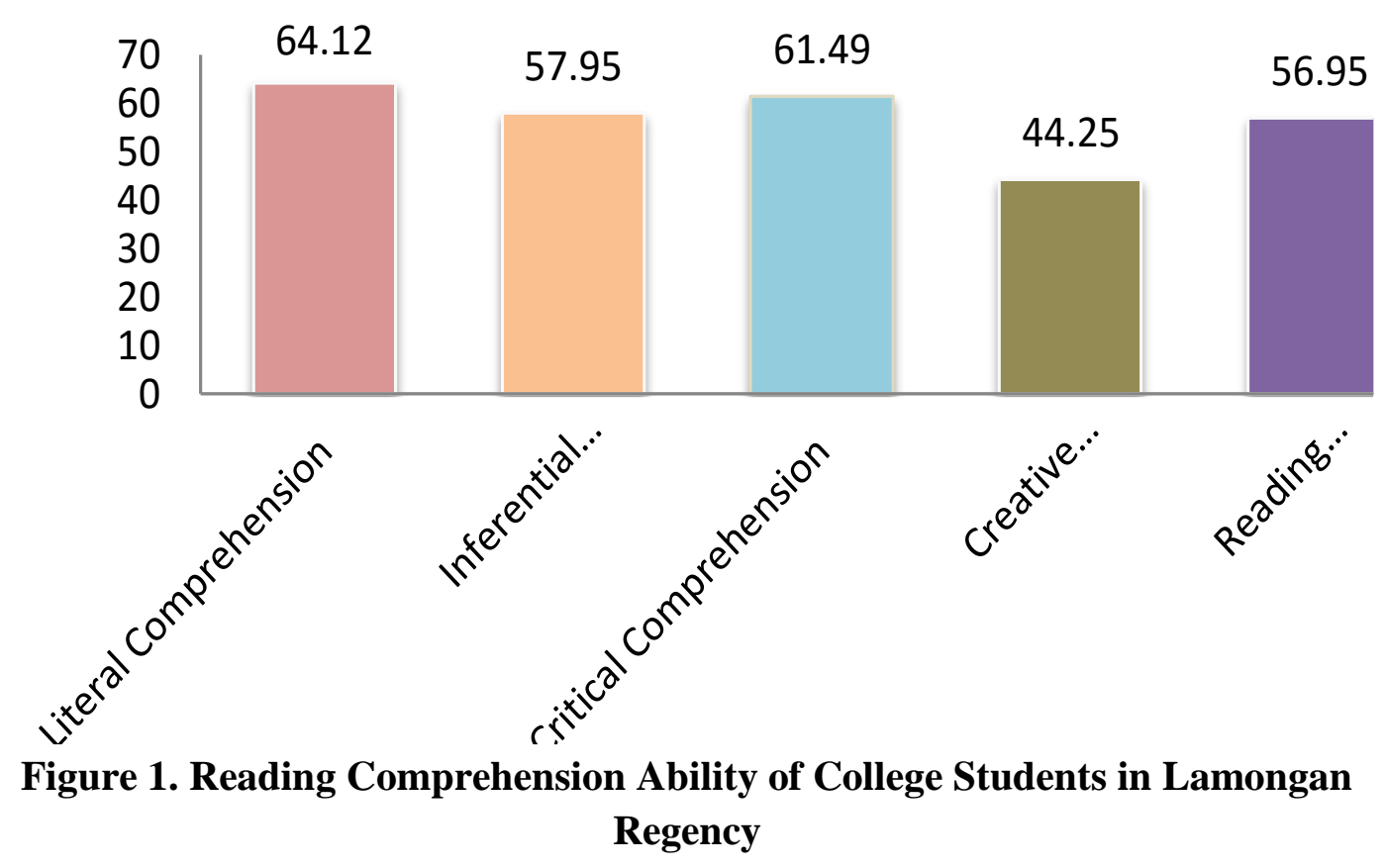

Based on these data the average acquisition value of the reading comprehension of college students in the Lamongan Regency was 56.95. From the average acquisition, it can be said that the level of reading comprehension of college students in the Lamongan Regency is at a moderate level. The acquisition is above from Solihin, Utama, Pratiwi, \& Novirina (2019) which states that the average national literacy index is 37.32 .

If it is related to LOTS and HOTS abilities stated by Kholiq \& Faridah (2019), the LOTS abilities of college students in the Lamongan Regency get an average score of 61.04. The acquisition of the LOTS ability of college students in the Lamongan Regency can be categorized high. HOTS's ability of university students in the Lamongan Regency gets an average score of 52.87. The acquisition of the LOTS ability of college students in the Lamongan Regency can be categorized as medium.

\section{CONCLUSION}

The Literal comprehension ability of college students in the Lamongan Regency at 64.12 with the high category. The inferential comprehension ability of college students in the Lamongan Regency was 57.95 in the medium category. The critical comprehension ability of college students in the Lamongan Regency was 61.49 with a high category. The creative comprehension ability of college students in the Lamongan Regency was 44.25 with a medium category. From the four results above, the reading comprehension ability of college students in the Lamongan Regency is at a moderate level with an average understanding value of 56.95. The acquisition is above the average national literacy rate of 37.32 . 


\section{REFERENCES}

Fitri, R. (2015). Kontribusi Minat Baca dan Penguasaan Kosakata terhadap Kemampuan Membaca Pemahaman Siswa Kelas X SMA Negeri 1 Padang Ganting Kabupaten Tanah Datar. Jurnal Gramatika Jurnal Penelitian Pendidikan Bahasa Dan Sastra Indonesia, 1(2). https://doi.org/10.22202/jg.2015.v1i2.1233

Gunawan, I., \& Palupi, A. R. (2016). Taksonomi Bloom - Revisi Ranah Kognitif: Kerangka Landasan untuk Pembelajaran, Pengajaran, dan Penilaian. Premiere Educandum: Jurnal Pendidikan Dasar Dan Pembelajaran, 2(2), 98-117. Retrieved from http://e-journal.unipma.ac.id/index.php/PE

Hidayat, A. (2017). Cara Hitung Rumus Slovin Besar Sampel. Retrieved from https://www.statistikian.com/2017/12/hitung-rumus-slovin-sampel.html

Irfadila, M. S. (2015). Hubungan Strategi Membaca dengan Kemampuan Memahami Teks Bacaan Bahasa Indonesia Mahasiswa Prodi Pendidikan Bahasa dan Sastra Indonesia FKIP UMSB Padang Panjang. Jurnal Gramatika Jurnal Penelitian Pendidikan Bahasa Dan Sastra Indonesiasa Dan Sastra Indonesia, 1(1). https://doi.org/10.22202/jg.2015.v1i1.1157

Kholiq, A., \& Faridah, F. (2019). Pencapaian High Order Thingking Skills (HOTS) dalam Membaca Pemahaman Mahasiswa Universitas Islam Lamongan. Lintang Songo: Jurnal Pendidikan, 2(2), 1-7. Retrieved from https://journal.unusida.ac.id/index.php/jls/article/view/333/267

Kholiq, A., \& Luthfiyati, D. (2018). Tingkat Membaca Pemahaman Siswa SMAN 1 Bluluk Lamongan. Reforma: Jurnal Pendidikan Dan Pembelajaran, 7(1), 1-11.

Laily, I. F. (2014). Hubungan Kemampuan Membaca Pemahaman dengan Kemampuan Memahami Soal Cerita Matematika Sekolah Dasar. Eduma: Mathematics Education Learning and Teaching, 3(1). https://doi.org/10.24235/eduma.v3i1.8

Marhiyanto, B. (2007). Pintar Bahasa Indonesia. Surabaya: Gitamedia Press.

Mulyati, Y., \& Isah, C. (2016). Keterampilan Berbahasa Indonesia SD (1st ed.). Jakarta: Universitas Terbuka. Retrieved from www.ut.ac.id

OECD. (2019). PISA 2018 Results Vol III: What School Life Means for Students' Lives. 2019 (Vol. III). Paris: OECD Publishing. https://doi.org/10.1787/acd78851-en

Patiung, D. (2016). Membaca sebagai Sumber Pengembangan Intelektual. Al Daulah: Jurnal Hukum Pidana Dan Ketatanegaraan, 5(2), 352-376. https://doi.org/10.24252/ad.v5i2.4854

Pebriani, Y. (2018). Peningkatan Kemampuan Membaca Pemahaman dengan Model Pembelajaran Kooperatif Tipe Student Team Achievement Divisions (STAD) Siswa Kelas VII SMP Semen Padang. Jurnal Gramatika Jurnal Penelitian Pendidikan Bahasa Dan Sastra Indonesiasa Dan Sastra Indonesia, 4(1). https://doi.org/10.22202/jg.2018.v4i1.1276 
Pettit, N. T., \& Cockriel, I. W. (1974). A factor study of the literal reading comprehension test and the inferential reading comprehension test. Journal of Reading Behavior, 6(1), 63-75. https://doi.org/10.1080/10862967409547078

Sartika, R. (2017). Kemampuan Menentukan Kalimat Fakta Suatu Tinjauan melalui Kegiatan Membaca Intensif Tajuk Rencana Harian Umum Singgalang Siswa Kelas X SMK-SMAK Padang. Jurnal Gramatika Jurnal Penelitian Pendidikan Bahasa Dan Sastra Indonesiajurnal Penelitian Pendidikan Bahasa Dan Sastra Indonesia, 3(1), 74-88. https://doi.org/10.22202/jg.2017.v3i1.1864

Solihin, L., Utama, B., Pratiwi, I., \& Novirina. (2019). Indeks Aktivitas Literasi Membaca 34 Provinsi. (L. Solihin, Ed.). Jakarta: Pusat Penelitian Kebijakan Pendidikan dan Kebudayaan, Badan Penelitian danPengembangan, Kementerian Pendidikan dan Kebudayaan.

Somadayo, S. (2011). Strategi dan Teknik Pembelajaran Membaca. Yogyakarta: Graha Ilmu.

Yulianto, B., Sodiq, S., \& Asteria, P. V. (2020). The Relevance of Standardization of Comprehension Reading Skills in 4.0 Era. In Proceedings of the International Conference on Research and Academic Community Services (ICRACOS 2019) (pp. 213-216). Paris, France: Atlantis Press. https://doi.org/10.2991/icracos-19.2020.45 
